\title{
Public Landscape Design for Residential Neighborhood in Coastal Areas
}

\author{
Yang Wang*, Yun Yu, Shuhang You, Ying Lin \\ Huadong Engineering Corporation Limited, Hangzhou 311122, China
}

Corresponding Author Email: wang_y6@hdec.com

https://doi.org/10.18280/eesrj.070408

Received: 12 September 2020

Accepted: 26 November 2020

\section{Keywords:}

public landscape design, design scheme, integrated design, residential neighborhood, life quality

\begin{abstract}
The quality of public landscape design for residential neighborhood has a direct impact on the living comfort of the neighborhood and the life quality of the residents. To improve our citizens' living standards, this paper summarizes the current status and ideas of public landscape design for residential neighborhood in Hangzhou city, Zhejiang province, China, with the landscape design scheme of Qiaosi-II River as an example, this paper gives a discussion on the strategies for the public landscape design of environmentalfriendly residential neighborhood in coastal areas, and the research results show that there are many problems with the public landscape environment in the residential neighborhood of Hangzhou city, to cope with these problems, this paper proposes a few detailed countermeasures for the public landscape design of multi-story and high-rise residential building neighborhood. From a global view, the landscape design scheme of Qiaosi-II River is an integrated design scheme of buildings and landscapes in various regions such as commercial area, health care area, fitness area, green area, and play area for kids, etc. The research in this paper provides a theoretical basis for the public landscape design of safe, comfortable, and livable residential neighborhood in coastal areas.
\end{abstract}

\section{INTRODUCTION}

The quality of public landscape has now been regarded as an important sign for the development level of a city. The design of landscape in residential area should be oriented at serving the people and satisfying their behavioral and psychological needs [1]. In a neighborhood, the landscape is closely related to the daily life of the residents, the design of the public landscape determines their recreation pattern, and directly affects their life quality, therefore, people are paying more attention to the quality of the overall living environment $[2,3]$.

With the growing attention on the relationship among human, environment, and architecture, scholars are probing deeper into this aspect, and they have proposed various criteria for improving public landscape and living environment quality in terms of safety, comfort, hygiene and convenience, and these criteria have been taken as the design standards of public landscape in residential areas for a long time [4].

In China, the construction of public landscape in residential neighborhood began in the 1980s. In the beginning, people's only focus is on pursuing greater greening area; then, they have gradually begun to pay attention to the functions of the green area and the accessibility of the green space; and now, the design of public landscape is laying greater emphasis on the living comfort of the residents, and aiming at creating a beautiful, safe, green, and livable environment with complete functions, facilities and services [5].

Public landscape design is an inter-discipline subject involving landscape architecture, ecology, geography, urban planning, and other disciplines, and it has different meanings in different subjects. In the process of architecture and landscape design, designers should comprehensively consider all surrounding environmental elements, create a harmonious relation between buildings and natural environment, and design a living space that is comfortable, convenient, and secure for people to live in $[6,7]$. Moreover, some scholars have pointed out that the beauty of the public environment is a high-level aesthetic demand of the residents, it is an indispensable element for building an environmental-friendly residential area [8], and the design of public landscape in residential neighborhood is a key to improving residents' life quality.

For this reason, this paper attempts to figure out the current status and ideas of public landscape design for residential neighborhood in Hangzhou city; with the landscape design scheme of Qiaosi-II River as an example, this paper gives a discussion on the strategies for the public landscape design of environmental-friendly residential neighborhood in coastal areas, in the hopes of providing a reference for building safe and comfortable public landscape in residential neighborhood.

\section{STATUS OF PUBLIC LANDSCAPE DESIGN OF RESIDENTIAL NEIGHBORHOOD IN HANGZHOU}

After the 21st century, the real estate development of residential buildings in Hangzhou was booming and entered a competition period, and this stage is a comprehensive development stage of housing diversification and quality improvement [9]. The large-scale construction of new districts in Hangzhou had promoted the development of high-level and diversified residential neighborhood in coastal areas [10]. To implement the principle of giving priorities to greening, infrastructures, and public service facilities, the construction of supporting facilities had kept pace with the construction of 
residential buildings, thereby realizing the development pattern of building sight-seeing, ecological, and livable residential buildings [11]. The design content of landscape in residential neighborhood includes many types, such as vegetation landscape, road landscape, venue landscape, hard landscape, water landscape, shelter landscape, simulated landscape and high-viewpoint landscape, etc., as shown in Figure 1.

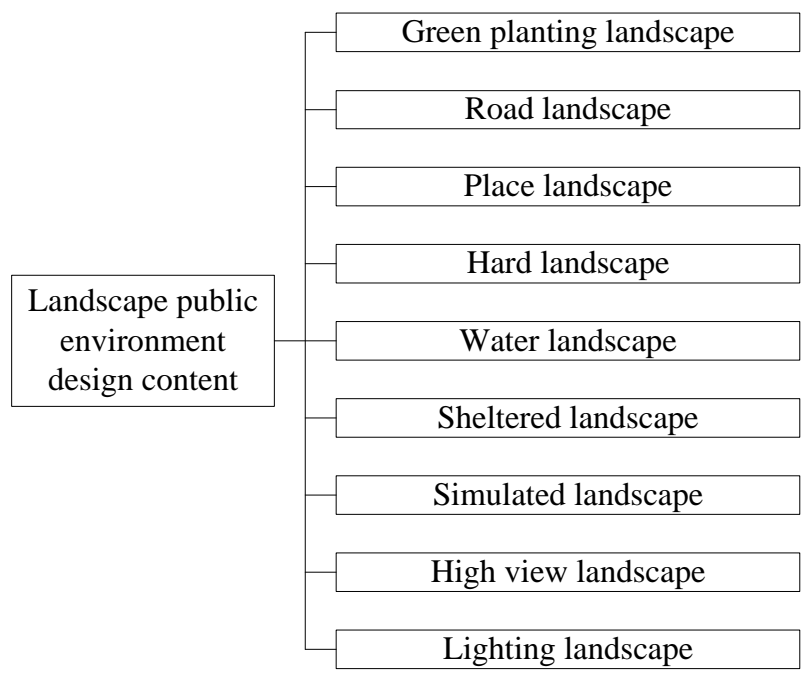

Figure 1. Design content of public landscape in residential neighborhood

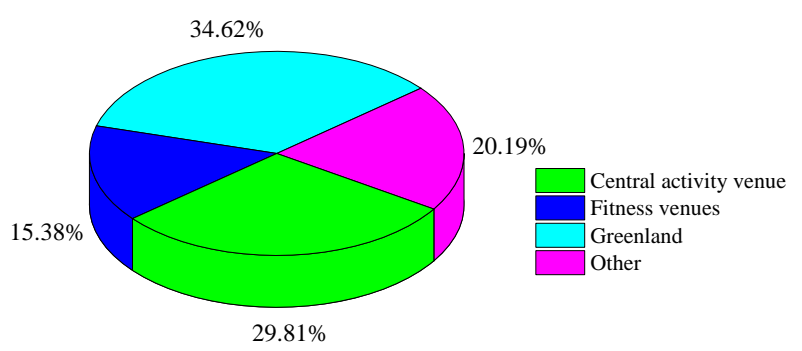

Figure 2. Statistics of land occupation rates of public landscape types in residential neighborhood of Hangzhou

The application of landscape resources and the utilization of landscape elements directly affect the functions of the landscape areas in the residential neighborhood and their practicality [12]. To figure out the spatial differences in the public landscape of residential neighborhood in Hangzhou, this study chose 26 typical residential neighborhood or communities from 4 districts in Hangzhou (Xihu district, Binjiang, district, Xiaoshan district, and Yuhang district) as the research objects, and nearly a thousand questionnaires were distributed. Figure 2 shows the statistics of land occupation rates of public landscape in residential neighborhood of Hangzhou, the average land occupation of central activity venue, fitness venue, and green space is $29.81 \%, 15.38 \%$ and $34.62 \%$, respectively. Scholars found that, with the continuous development of urban areas in Hangzhou, there are many problems with the public landscape in the residential neighborhood, such as too-large or too-small outdoor activity venues, too few plant species and quantities, water pollution problem with the greening in the area, etc. [13]. Most of the existing buildings are high-rise architectures which lack the connection with surrounding environment, many residents do not have good landscape environment, and their living environment lacks the connection with natural environment [14]. The design of public landscape in residential neighborhood includes activity landscape, exercise landscape, and green landscape, etc. [15]

\section{DESIGN IDEAS AND PLANNING COUNTERMEASURES FOR PUBLIC LANDSCAPE IN RESIDENTIAL NEIGHBORHOOD}

\subsection{Design ideas}

As an important part of residential neighborhood, the public landscape environment is an important measure for the quality of the neighborhood environment in the communities [16]. The government of Hangzhou recommends adopting a design mode integrating planning, landscape, and architecture, which can better arrange various green spaces in the neighborhood, appropriately apply design ideas according to local conditions, and flexibly build ecological and suitable residential areas [17]. As for the landscape layout, it's also recommended to adopt a balanced layout that pay more attention to the compatibility and equilibrium of the landscape, and can evenly arrange the central green space, the surrounding green space, and the green space combinations [18]. For multi-story residential building neighborhood, the landscape is mostly public green space, and the design of landscape emphasizes on the homogeneity and the harmonious co-existence of residential buildings and the landscape environment. Different residential areas should have different public landscape design schemes, and it is necessary to systematically analyze the landscape design schemes of each evaluation object, the flow of the selection of public landscape environment indicators is shown in Figure 3. First, the design object and design objectives of public landscape in residential neighborhood should be clarified; then according to the design schemes of different objects and the specific performance requirements, the connotations and expressions of the indicators are determined, and the indicator system is constructed based on the systematic, comprehensive, operable, and scientific principles [19]. Figure 4 lists the principles of public landscape design, including safety design principles, function design principles, aesthetics design principles, participation design principles, identifiability design principles, and humanity design principles.

\subsection{Planning countermeasures}

The design scheme of public landscape in residential neighborhood has an impact on the overall landscape features of the communities, and the planning of the landscape layout should well manage the relationship among the residential buildings, roads, green space, and public buildings [20]. Figure 5 enumerates the planning countermeasures for public landscape in residential neighborhood, which are divided into two parts, planning countermeasures for multi-story residential building neighborhood, and planning countermeasures for high-rise residential building neighborhood. For multi-story residential buildings, the landscape design should: (1) fully respect and utilize the natural ecology of the construction site; preserve woodland, large trees, and natural water bodies in the area as much as possible; reduce the number of building unit combinations; (2) cancel the planning of large-area central green space; connect green spaces in front of each building to form a landscape axis 
with full functions [21]; (3) create "natural courtyards without boundaries" that can blend in artificial greening and natural landform completely. For high-rise residential buildings, the landscape design should: (1) integrate and design the entire residential area as a whole, so that the overall landscape would have a uniform visual effect, and the quality of the landscape environment would be better; (2) arrange residential buildings with less entrance, smaller frontage width, and greater room depth in the geometric center of the residential area or building cluster, so that the area of residential buildings in the central area is the minimum and the area of surrounding green space is the maximum; (3) pay attention to the layout of plane functions and the use of vertical spaces, enrich the landscape structure hierarchies of residential neighborhood, and weaken the oppressive feelings brought by high-rise buildings.

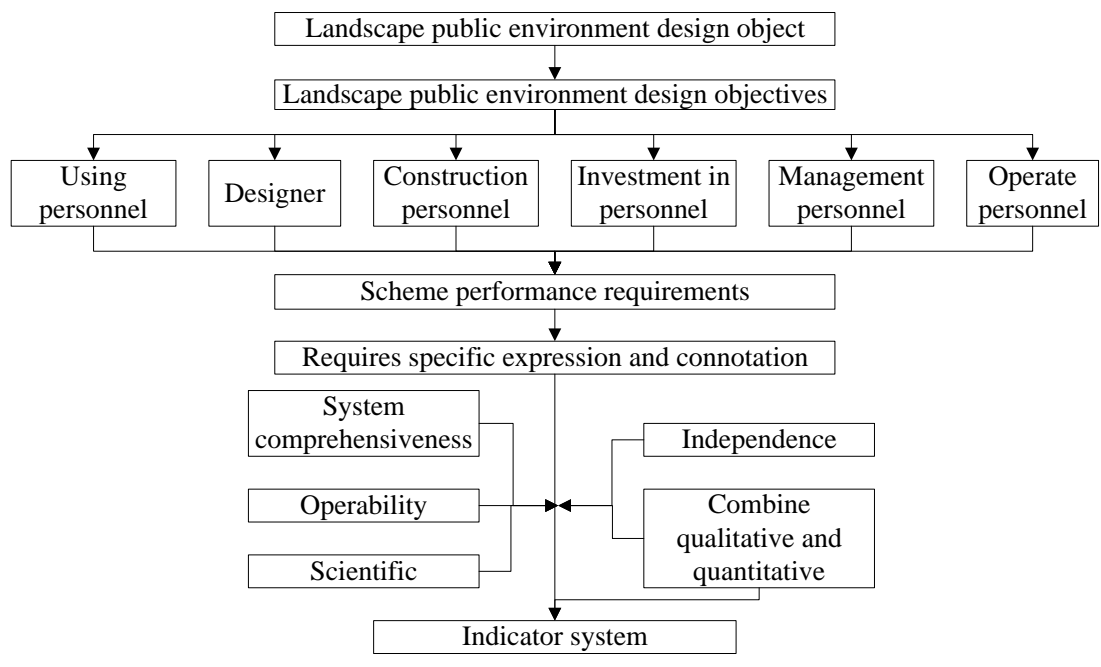

Figure 3. Flow of selection of public landscape environment indicators

\begin{tabular}{|c|}
\hline Safety design principles \\
\hline $\begin{array}{c}\text { Design principles of } \\
\text { public environment of } \\
\text { residential landscape }\end{array}$ \\
\cline { 2 - 3 }
\end{tabular}

Figure 4. Design principles of public landscape in residential neighborhood

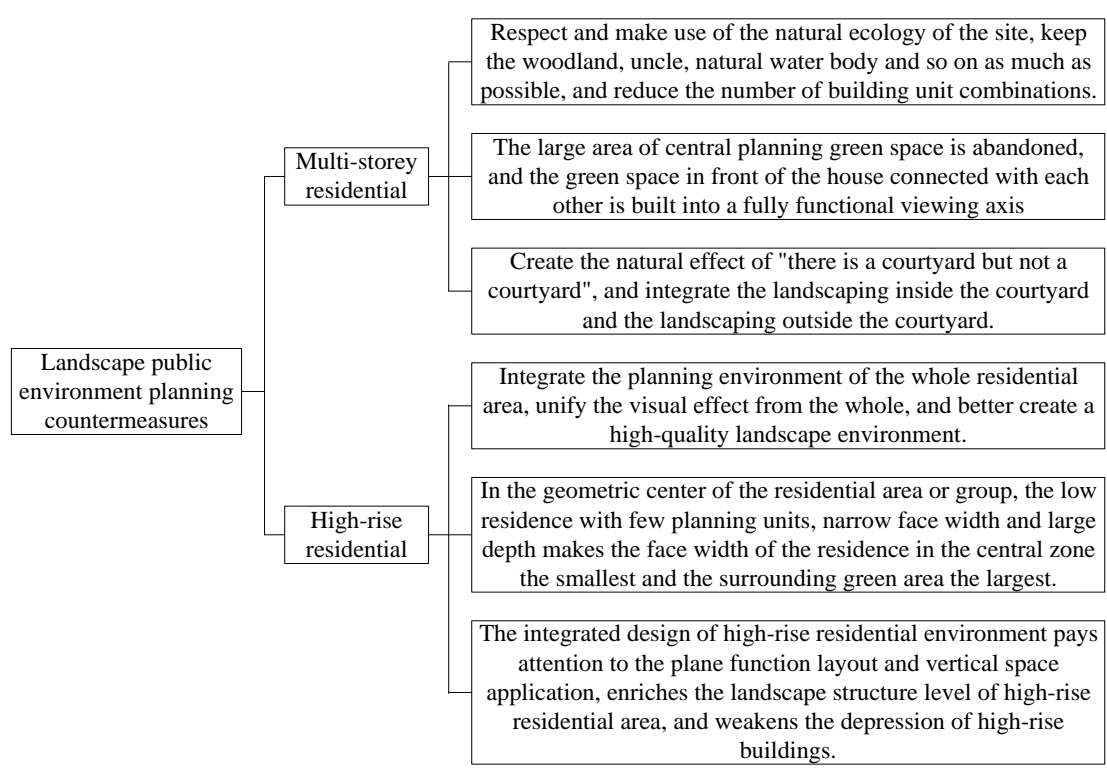

Figure 5. Planning countermeasures for public landscape in residential neighborhood 


\section{CASE STUDY - LANDSCAPE DESIGN SCHEME OF QIAOSI-II RIVER}

\subsection{Project overview}

The sample case includes the following areas: the area on both sides of Donghu South Road and Jiadong Road, along the green belt, the area reaches Hangzhou Ring Expressway (G2501) in the north, and Sanwei Road in the south; the greenbelt area on both sides of Fangtangbu River, which extends to Shihaopu in the west and Donghu South Road River in the east; the green belt area along the north side of Sanwei Road, which extends to Tongsheng Road in the west and Donghu South Road in the east; 2\# River to the north of Fengshou Lake, Shihaopu to the south of Fengshou Lake, and other greenbelt nodes. The total design area is about 658,000 square meters, of which the length of the greenbelt is about 12 kilometers, and the length of the riverway reinforcement construction project is about 3.2 kilometers. The overall planning of the greenbelt system is designed based on a continuous open space system, then the functional areas of each open space are determined, and finally, a spatial structure with "one center, one axis, three rings, eight lines and multiple nodes" is formed, as shown in Figure 6.

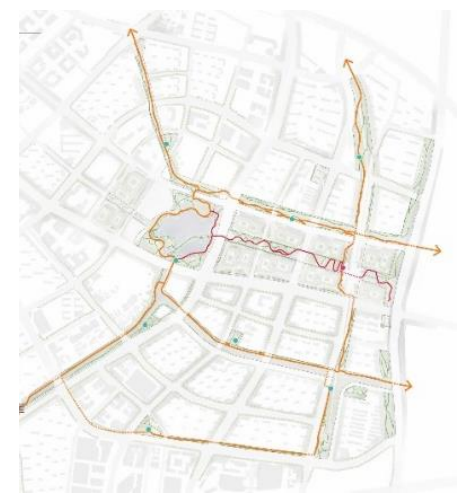

Figure 6. Spatial structure layout of the greenbelt system

\subsection{Design ideas and strategies}

From a global view, the landscape design scheme of QiaosiII River is an integrated design scheme of various venues, buildings and landscape in the region, it has carefully designed the roads and paths in the area and fully respected the original ecology of the site. The overall design takes the landscape of Fengshou Lake as the center, the Wisdom Valley Innovation Park as the green axis; it designs two waterfront industrial corridors, two image display corridors, and four waterside life corridors; and it also includes the planning of multiple communities. The landform of the site is mostly farmland, and the terrain is flat; based on a general idea of "expanding the

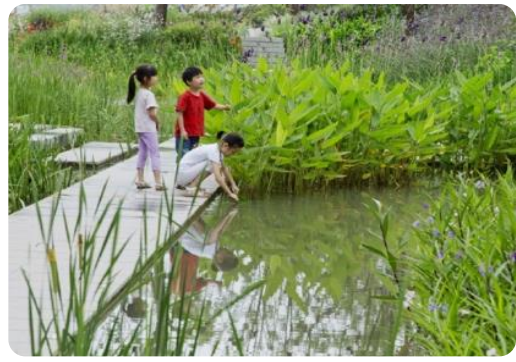

(a) Play area for kids storage area of the lake and dredging the main riverways", a storage lake of the Fengshou Lake is planned and the central lake area is designed to cover an area of $0.06 \mathrm{~km}^{2}$, the lake can reduce the drainage pressure of the planned commercial area in case of heavy rains. Then, through the riverway reinforcement construction project, the design scheme plans a new port, the Triangle Port, and two new rivers, the Jiubao \#1 River and \#2 River, to break the water blocks, and unclog the water system, thereby forming a main drainage river network system of the commercial area and ensure the smooth drainage of the site.

Figure 7 shows a few sketches of the landscape design scheme of Qiaosi-II River, it includes commercial area, health care area, fitness area, green area, and play area for kids, etc. Based on the overall layout of the greenbelt system, the designed greenbelt in this scheme is located on the east side of the site, it runs through the area and leads visitors from the Ciyuan Road to the site. Figure 8 gives a few photos of public landscape in some other residential areas. Figure 8(a) is a play area for kids, a mirror gallery introduces visitors into the area, and an iris-themed waterfront plant science garden built based on the original water environment provides residents and kindergarten children with more opportunities to get close to and learn about nature [20]. Figure $8(b)$ is a health care area for residents, it makes use of the high density of negative oxygen ions in the waterfront tree-shaded environment in the afternoon and provides a green and health-keeping venue for residents. Figure $8(\mathrm{c})$ is a digital peninsula, it is a leisure space surrounded by technological landscapes, and it can inspire the residents to think about the connection between technological development, city, and life. Figure 8 (d) is a commercial and leisure area, it provides a comfortable outdoor dating space for surrounding staff and residents; based on the characteristics of the site, the design makes use of the vertical space and turns it into a place where residents can stay and take rests, the design combines the site functions with its characteristics [22-24].

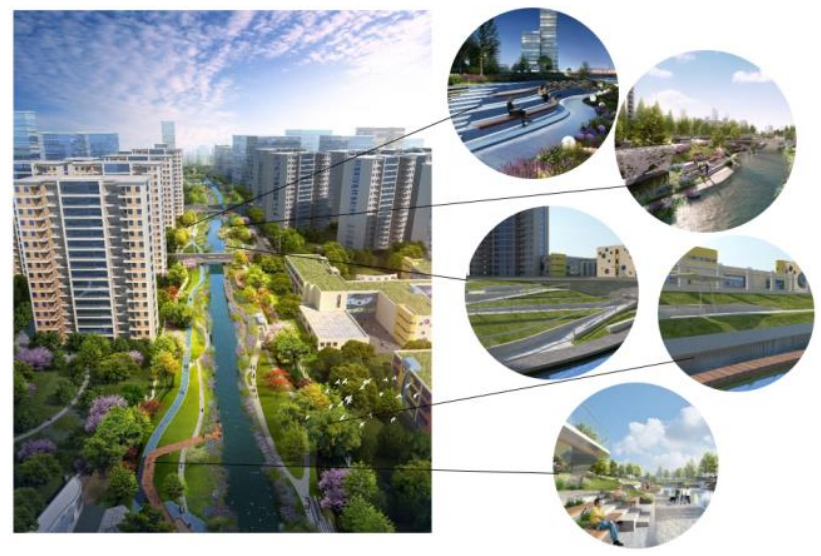

Figure 7. Sketches of the landscape design scheme of Qiaosi-II River

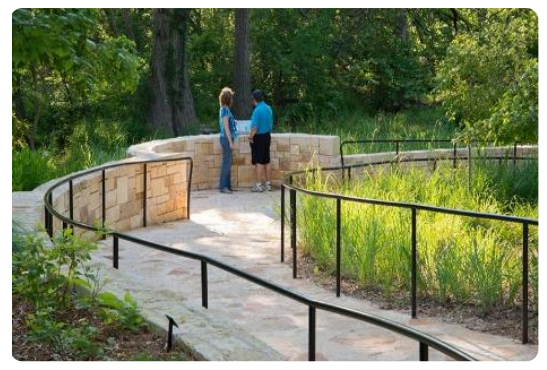

(b) Health care area 


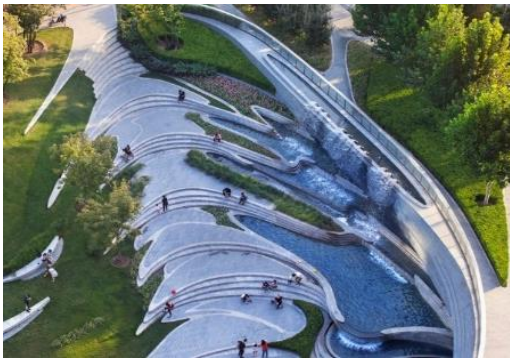

(c) Digital peninsula

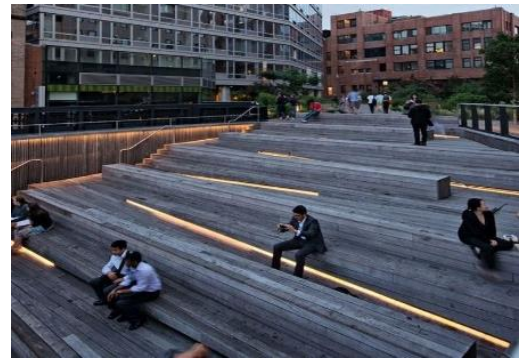

(d) Commercial and leisure area

Figure 8. Example photos of public landscape in residential neighborhood

\section{CONCLUSION}

This paper studied the current status and ideas of public landscape design for residential neighborhood in Hangzhou city, with the landscape design scheme of Qiaosi-II River as an example, it discussed the strategies for the public landscape design of environmental-friendly residential neighborhood in coastal areas. The specific conclusions are as follows:

(1) The principles of public landscape design include safety design principles, function design principles, aesthetics design principles, participation design principles, identifiability design principles, and humanity design principles.

(2) The design scheme of public landscape in residential neighborhood has an impact on the overall landscape features of the communities, and the planning of the landscape layout should well manage the relationship among the residential buildings, roads, green space, and public buildings.

(3) The overall planning of Qiaosi-II River forms a spatial structure of "one center, one axis, three rings, eight lines and multiple nodes", from a global view, it gives an integrated design of buildings and landscapes in various regions such as commercial area, health care area, fitness area, green area, and play area for kids.

\section{ACKNOWLEDGMENT}

We thank Zhe Li, MeiFu Xu, Rui Fu and YuKun He for their indispensable help with this research, we also thank for the data support from the Digital Landscape Laboratory of Southeast University. The authors are grateful to the reviewers and the editors for the time and effort they put into their detailed comments that helped improve this paper.

This research is supported by POWERCHINA HuaDong Engineering Corporation Limited (HDEC, No. KY2019-JZ43).

\section{REFERENCES}

[1] Lipovská, B. (2013). Assessing observation methods for landscape planning practice in rural villages. Current Urban Studies, 1(4): 102-109. http://dx.doi.org/10.4236/cus.2013.14011

[2] Li, D., Liu, M., Liu, J. (2020). Design strategy of rural settlement landscape: A case study of Xinji Village in Beijing. Journal of Landscape Research, 12(2): 26-36. http://doi.org/10.16785/j.issn1943-989x.2020.2.006

[3] Wang, Y., Zhang, F. (2016). Making public space in high-density environment: strategy and methodology of landscape urbanism. Journal of Landscape Research, 8(3): $\quad 53-59$. http://doi.org/10.16785/j.issn1943989x.2106.3.015

[4] Makhzoumi, J., Al-Sabbagh, S. (2018). Landscape and urban governance: Participatory planning of the public realm in Saida, Lebanon. Land, 7(2): 48. http://doi.org/10.3390/land7020048

[5] Santé, I., Tubío, J.M., Miranda, D. (2020). Public participation in defining landscape planning scenarios and landscape quality objectives (LQO): Landscape Guidelines for Galicia (NW Spain) case study. Land Use Policy, 94: 104559. http://doi.org/10.1016/j.landusepol.2020.104559

[6] Jaglarz, A. (2018). Architecture of public toilets in the landscape - disorder or integration. Advances in Human Factors, Sustainable Urban Planning and Infrastructure, 788: 364-376. http://doi.org/10.1007/978-3-319-94199$8 \_35$

[7] Qin, Y., Chen, X.G. (2017). Space landscape design strategy of cave dwelling settlement in guanzhong region. Journal of Landscape Research, 9(3): 30-36. http://doi.org/10.16785/j.issn1943-989x.2017.3.008

[8] Viola, S. (2017). Technological innovation, design and inclusiveness for the manufacturing landscapes. European Journal of Sustainable Development, 6(3): 271-271. http://doi.org/10.16785/10.14207/ejsd.2017.v6n3p271

[9] Hami, A., Moula, F.F., Maulan, S.B. (2018). Public preferences toward shopping mall interior landscape design in Kuala Lumpur, Malaysia. Urban Forestry \& Urban Greening, 30: 1-7. http://doi.org/10.1016/j.ufug.2017.12.019

[10] Yu, J.E. (2015). A Study on the change and factors of landscape facilities shown in a landscape architecture magazine. Journal of the Korean Institute of Landscape Architecture, 43(5): 111-120. http://doi.org/10.9715/KILA.2015.43.5.111

[11] Carlier, J., Moran, J. (2019). Landscape typology and ecological connectivity assessment to inform Greenway design. Science of the Total Environment, 651: 32413252. http://doi.org/10.1016/j.scitotenv.2018.10.077

[12] Soowczuk, A. (2020). Effect of landscape elements and structures on the acoustic environment on wildlife overpasses located in rural areas. Sustainability, 12(19): 7866. http://doi.org/10.3390/su12197866

[13] Li, Z., Han, X., Lin, X., Lu, X. (2020). Quantitative analysis of landscape efficacy based on structural equation modelling: empirical evidence from new chinese style commercial streets. Alexandria Engineering Journal, 60(1): 261-271. 
http://doi.org/10.1016/j.aej.2020.08.005

[14] Verderber, S. (2014). Residential hospice environments: evidence-based architectural and landscape design considerations. Journal of Palliative Care, 30(2): 69-82. http://doi.org/10.1177/082585971403000202

[15] Luo, D., van der Heijden, H., Boelhouwer, P.J. (2020). Policy design and implementation of a new public rental housing management scheme in China: A step forward or an uncertain fate? Sustainability, 12(15): 6090. http://doi.org/10.3390/su12156090

[16] Xu, J., Xiao, W., Mao, Z. (2019). Research on design scheme of urban public transportation for energy conservation. IOP Conference Series: Earth and Environmental Science, 300(4): 042027. http://doi.org/10.1088/1755-1315/300/4/042027

[17] Lu, Y., Chen, L., Yang, Y., Gou, Z. (2018). The association of built environment and physical activity in older adults: using a citywide public housing scheme to reduce residential self-selection bias. International Journal of Environmental Research and Public Health, 15(9): 1973. http://doi.org/10.3390/ijerph15091973

[18] Radifan, H., Amiruddin, A. (2019). Design and theoretical analysis of the application of the certificateless public key encryption scheme for home monitoring system security. IOP Conference Series: Materials Science and Engineering, 508(1): 012131. http://doi.org/10.1088/1757-899X/508/1/012131
[19] Li, Z., Cheng, Y., Xiao, R. (2018). Electroencephalogram experiment based analysis of aesthetic fatigue on chinese traditional garden. NeuroQuantology. 16(5): 356-362. http://doi.org/10.14704/nq.2018.16.5.1296

[20] Zhang, X., Li, S. (2020). Application of psychological elements in landscape design of public gardens. Revista Argentina de Clínica Psicológica, 29(2): 142-149.

[21] Li, Z., Cheng, Y.N., Song, S., He, Y.K. (2019). Research on the space cognitive model of new Chinese style landscape based on the operator optimization genetic algorithm. Fresenius Environmental Bulletin, 28(6): 4483-4491.

[22] Zhang, X., Li, S. (2020). Landscape pattern and design for the ecosystem in constructed wetland. Environmental Engineering and Management Journal, 19(9): 1459-1465.

[23] Li, Z., Cheng, Y., Yuan, Y. (2018). Research on the application of virtual reality technology in landscape design teaching. Educational Sciences: Theory \& Practice, 16(5): 1400-1410. http://doi.org/10.12738/estp.2018.5.037

[24] Zhang, X.L. (2018). Practice teaching of landscape survey course based on ecognition remote sensing image interpretation technology. Educational Sciences-theory \& Practice, 18(5): 1411-1423. https://doi.org/10.12738/estp.2018.5.038 